IJAMSR 3 (7) www.ijamsr.com CrossRef: https://doi.org/10.31426/ijamsr.2020.3.7.3512

International Journal of

Advanced Multidisciplinary Scientific Research (IJAMSR) ISSN:2581-4281

\title{
EDUCATIONAL RIGHTS OF CHILDREN, ISSUES AND CHALLENGES
}

\section{Dr. Rayees Ahmad Dar}

Faculty of Education University of Kashmir, Kashmir, India.

Email: rayees78601@gmail.com

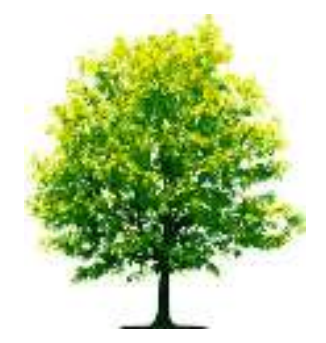

Keywords:

Educational rights, Independent India, issues, solution

\begin{abstract}
A B S T RA C T
Child rights assume great significance in a civilized society because children are human beings who have rights to safety, security and opportunities for full development. Human resource is important part of any country and it can be developed through Education especially by strengthening the basic Education. Education is considered to be the way to lead towards progress and development of the individual. After independence of India constitution guarantee free and compulsory elementary education. On 15thof August 1947 India got freedom from British dominance. After independence India got opportunity to make the system/platform to give Education to the maximum population of the country, Indians get opportunity to make modification in the previous system and their Educational policies according to the need of the country. Starting from University Commission, Secondary Education Commission, and Hunter Commission, many other policies, programmes, Acts and commissions are establish but till now Educational rights of children are not fulfilled. They are denying their Educational rights in one and other forms. Starting from the family to school and from school to society they are discriminated and denied by one and another reason.
\end{abstract}

Citation: Rayees Ahmad Dar (2020). Educational Rights Of Children, Issues And Challenges. International Journal of Advanced Multidisciplinary Scientific Research (IJAMSR) ISSN:2581-4281, 3 (7), July 2020, Pp 14-23 
IJAMSR 3 (7) www.ijamsr.com CrossRef: https://doi.org/10.31426/ijamsr.2020.3.7.3512

\section{International Journal of \\ Advanced Multidisciplinary Scientific Research (IJAMSR) ISSN:2581-4281}

\section{Introduction}

Education in the largest sense is an act or an experience that has a formative effect on the mind, character or physical ability of an individual. In its technical sense, education is the process by which society deliberately transmits its accumulated knowledge, skills and values from one generation to another of society. Education in real sense is to humanize humanity and to make life progressive cultured and civilized. It is very important for the progress of the individual and society. It is through education that man develops his thinking and reasoning, problem solving and creativity, intelligence and aptitude, positive sentiments and skills, good values and attitudes. Education is a dialogue between the past, present and the future, so that the coming generations receive the accumulated lessons of the heritage and carry it forward (UNESCO, 1998). Soon after gaining independence in 1947, this was the first priority of the government of India that making Education accessible for all without any discrimination. As India is the hub of Discrimination even after independence, there is discrimination on the basis of caste, color, creed, gender and religion, but Indian constitution has provisions which prevent the rights of all the people of the country. As the Article 14 to 18 of the Indian Constitution indicate that everybody is Equal. There is no discrimination on the basis of the color creed sex gender etc. The 86th constitutional amendment has also made elementary education a fundamental right for the children between the age group 6 to 14 . Corporal punishment, physical punishment, emotional abuse, negative reinforcement, sexual abuse, in Indian schools is the great threat to the protection of Childs Educational Rights. India is the country of younger population. According to the census 2011 children below fifteen year is 25.5 million in India. National Commission for Protection of child's Rights ensures the protection of the rights of all children in India. The National Commission for Protection of Child Rights and the State Commissions for Protection of Child Rights works for observing children's right to education under Right of Children to Free and Compulsory Education Act, 2009. The latest data on the child's rapes revealed that employers and co-workers are the offenders in $25 \%$ of cases. National Crime Bureau's (NCRB) data revealed that 8800 cases of rapes of children were registered across the country in 2015. This was the first time in 2015 that 
IJAMSR 3 (7) www.ijamsr.com CrossRef: https://doi.org/10.31426/ijamsr.2020.3.7.3512

NCRB tabulated data terms of the relationship of the victim and the accused. The data shows that neighbors were the biggest abusers of children in 2015. It has been found that out of 3149 cases, $35.8 \%$ of abusers were neighbors and over $10 \%$ family members raped the children. (Indian Express, 2016). Many of the families in India do not have enough money to meet the basic necessities of life, which forces the parents to sell their children, which is the cause of depriving from their Education. Child marriage in India, according to the Indian law, is a marriage where either the woman is below age 18 or the man is below age 21 . But in India, most of child marriages involve underage women, many of whom are in poor conditions. Child marriage is one of the hurdles in attaining the Educational success of the country. It has been estimated that 14 million adolescents whose age is in between 15 and 19 gives birth each year. It is evident to say that they are not only depriving from their Educational rights but they are not even attaining the personal and civil rights.

\section{Objectives of the Study}

a) To consider the Educational rights of the children in context of Independent India. b) Factors responsible which became the hurdles to attain Educational rights of the children.

c) To find out ways and means to equal access of Educational Rights of children in India.

\section{Methodology or Data Source}

This conceptual paper is based on secondary information collected from different sources such as books, journal articles, reports of various government organization and commission, articles, newspapers etc. just after the interdependence implementation of the constitution of India in 1950 it has been incorporated in the 'directive principles of state policy', that "All states shall endeavor to provide within 10 years of commencement of constitution free and compulsory education to children till they reach the age of 14 years" (Constitution, 1950). At that time the literacy of India were only $16 \%$. It was evident that it was the responsibility of the state to prove the primary Education to the children and Higher Education was under the Centre. The another step taken by the government in 1976 that Education became a concurrent subject, due to which it becomes the responsibility of the state 
IJAMSR 3 (7) www.ijamsr.com CrossRef: https://doi.org/10.31426/ijamsr.2020.3.7.3512

and Centre both to deal with Education system.

After that there was National Policy on Education (NPE) which came in 1986, which defined and recommended Universal Elementary Education. The focus of the NPE 1986 on the Areas such as Universal access, universal retention and universal attainment of Elementary Education. National Policy on Education also recommended Common School System. But the most the policies remained only in the pages, they are neither enforceable nor justifiable and the target of India to achieving Elementary Education remained dead. The right of attaining Education is not fulfilled yet. It has been estimated that millions of children in rural areas and urban slums denied from the basic Education and it is only a dream for them to gain Education. In spite of numerous policies and bills on education presented in Parliament of India since time of Independence in 1947. For that Government claims that its "revolutionary", 'Right to Education Bill' (RTE), which will solve the problem of providing every child between age group of 6-14 years, the right to free and compulsory education.

\section{Issues and Challenges}

\section{Child Marriage in India Leads to denial for}

\section{Education:}

According to the constitution of India the legal age of marriage for girls is 18 years and for boys is 21 years. Any marriage which solemnized before this age is considered as child marriage. It affects both girls and boys. It becomes the hindrance in achieving desired Education. It has been reported that Child marriage down since 2001 but still rampant, and it has been found that trend of underage marriages common to Hindus and Muslims. In India Seventy Eight lakh girls were married even before they had turned 10. The latest Census report (2011) reveals that child marriage is rampant. It has been estimated that percentage of underage marriage is lowest among Sikhs and highest in Hindus, shows data census 2011 which force the children to leave the school. It is the point of Discussion that Educational Rights of Children: Issues, Challenges and Solution. What factors are there in India which forced to child Marriage and not to Education? The reasons may be Poverty, Orthodoxy, and unawareness about benefits of Education in future and how it contributes personal social and societal 
IJAMSR 3 (7) www.ijamsr.com CrossRef: https://doi.org/10.31426/ijamsr.2020.3.7.3512

\section{International Journal of \\ Advanced Multidisciplinary Scientific Research (IJAMSR) ISSN:2581-4281}

development. Child Trafficking and denial of Education: Childhood age is to be considered as the age of learning, playing and enjoying. It is the crucial age to make the base of the future Education. But a country like India even after seventy years of Independence has no control on Child trafficking. Rules and regulations have made but the proper Implementation is not there. It has been estimated that 15,212 children have been kidnapped and abducted in 2014 in India. The question arises here is who will secure the future of these children? Who is responsible for their protection? How India will achieve the goal of Universalization of Elementary and Secondary Education? Almost 20,000 women and children were victims of human trafficking in India in 2016, a rise of nearly 25 percent from the previous year. The Ministry of Women and Child Development told parliament that 19,223 women and children were trafficked last year against 15,448 in 2015 , with the highest number of victims recorded in the eastern state of West Bengal.

\section{Child Victims of Domestic Violence:}

Domestic violence is the cause which affects the Education of the children. Pattern of abusive and coercive behaviour of intimate partners by using, physical, sexual and psychological attacks reduced academic progress and increased disruptive or unfocused classroom behaviour for children, adolescents, and teenagers. Children from dysfunctional families are less likely to function successfully at school (Valerie Garnett 2013). As per the victimization of children by domestic violence is concerned that more than 275 million of children become the victim of domestic violence every year (UNICEF). And these perpetrators mostly include parents and other close family members. It has also been reported by the UNICEF that domestic violence has long-term physical and psychological damage that impairs the ability of the children to learn and socialize, it makes difficult for students to perform well in school. It has been indicated by Studies from some of the largest countries in the developing world, including China, Colombia, Egypt, India, Mexico, the Philippines and South Africa, that there is a strong correlation between violence against women and violence against children. 
IJAMSR 3 (7) www.ijamsr.com CrossRef: https://doi.org/10.31426/ijamsr.2020.3.7.3512

\section{Violation of Rights of Education due to}

\section{Child sexual abuse:}

Bahadur Singh conducted a study based on a well-designed methodology, which covered 13 states including states with the highest through to the lowest crime rates incidents of offences against children. 18-20\% of Child Sexual Abuse occurs in the family and around $50 \%$ of these cases are being registered from institutional settings (Jota Baldur). Girls are more vulnerable to sexual abuse. Sexual exploitation and abuse is strongly correlated to poverty. (Jota Belur and Bahadur Singh 2015). According to Recent data on prevalence of sexual abuse in schools and/or anywhere in South Asia, India has $49.9 \%$ of 4320 are sexual abused in schools.

\section{Child Labor and Educational Rights of the Children:}

Child labor is most prevalent in India. Children ranging from Kashmir to Kanyakumari found working in unorganized sector, workshops, establishments, mines and in the service sector at times as domestic help, whether paid or unpaid. The age which is the initial stage for getting formal education is spent working as shoe-shine boys, working on shops, rag-pickers and are even found begging. And it is evident to say that Most of the children are bonded into labor being forced either by their parents or due to lose of parents. In this regard Children are known to drop out of school and accompany their parents by earning money in one and another way.

\section{Corporal Punishment and Educational \\ Rights of children:}

The right to Education act 2009 is totally against the Corporal punishment but still Indian schools uses corporal punishment and it is against the human right based approach to Education. Along with this it is not only restricted to schools alone, it can be pain caused by parents at home or any other violent action intended to discipline children or to punish them. Corporal punishment may be in the form of making the child run in the school ground, asking them to stand up for long hours, asking them sit like a chair, beating them with stick, pinching or slapping etc. the other ways like abusing them sexually, torturing them. It can lead to physical and mental injury, and even death of the children in some cases. 
IJAMSR 3 (7) www.ijamsr.com CrossRef: https://doi.org/10.31426/ijamsr.2020.3.7.3512

\section{Solution to Equal Access to Education with}

\section{Equal Educational Rights}

As India is the country having 45 percent of girls are wedded below 18 year. The girls who married below the age of 18 year are majority of them from poor and below poverty line (BPL) families. India is incapable of removing this malpractice from the society which is the great hindrance in the development of the nation. As it has found by studying reports and researches it is essential to suggest that there is a need to laid light on the poverty and illiteracy which is the cause of child marriage. For this there is a need of implementing the policies at ground level. A mechanism needs to be establish in Gram/ village level to register the cases and financial support needs to be given the poor families so that they can sent their children to school. And strict action needs to be taken on those who commit the same. As government of India is opening the school in all rural and far-flung areas but there is very less enrolment and high dropouts, the reasons are unawareness, poverty and illiteracy and social causes as well. As per the child trafficking is concerned again it comes in front that the reason behind it is either poverty, social exclusion, illiteracy and unawareness among the parents and the society. As the researcher above mentioned the figures of trafficked children in India, there is a need of strict rules, regulations, laws and willingness of various stakeholders to prevent children from trafficking. Again researcher suggesting on the basis of evidences that poor families should be financial supported so that the parents do not send their children to some work in hazardous places which is against the rights of children and they should be made aware about the need of Education in future progress and nation building. As per the victimization of children by domestic violence is concerned that more than 275 million of children become the victim of domestic violence every year (UNICEF). It has also been reported by the UNICEF that domestic violence has long-term physical and psychological damage that impairs the ability of the children to learn and socialize, it makes difficult for students to perform well in school. This is one of the causes of the violation of Educational rights of children. The violence in the home affects the Education of the children. For that local authorities should take care of the local area, i.e. Panchayat can play a significant role in protection of domestic violence against children. Government should direct the Local authorities to consider these 
IJAMSR 3 (7) www.ijamsr.com CrossRef: https://doi.org/10.31426/ijamsr.2020.3.7.3512

issues. And local government should ensure the retention of the children. School management committee should be authority to check the cases of domestic violence and violation of Educational Rights. As the researcher above mentioned the status of sexual abuse against children in the home and school leads to violation of Educational Rights of children. Girls are more vulnerable than boys in regard to sexual abuse. Again poverty is the root cause which needs to diminish. The first focus of every stakeholder is to remove the poverty from the country which is the first factor of every violence in Indian society.

Child labor is most prevalent in India. This is the point of the consideration that from Kashmir to Kanyakumari children are not getting there due share in receiving Education, Every Educational policy is getting fail in India and child labor is one of the great threat to the progress of the country which needs to be addressed. India got Independence in 15th of Aug, 1947, but the problem of Child labor is not yet solved. Below poverty Line families should be financially supported and special schemes needs to be implemented for the children who are below poverty line. Corporal punishment is the biggest threat in Indian schools. Corporal punishment due to weakness in study and on the name of castes and religion. This intolerance among the teachers violates the Educational Rights of the children. There are many cases in India against teachers where students commit suicide due to pressure of the teacher and administration. Hence it is necessary to incorporate the matter related to Childs rights, protection of human rights in teacher Education curriculum and there is need of organizing in-service programmes and workshops so that they can get aware about the sensitization of Childs Educational Rights. Strict rules to be followed in the schools. Panchayat and village Education committee should ensure the protection of the children in the schools.

\section{Conclusion}

On 15th of August 1947 India got freedom from British dominance. After independence India got opportunity to make the system/platform to give Education to the maximum population of the country, Indians get opportunity to make modification in the previous system and their Educational policies according to the need of the country. Starting from University Commission, Secondary 
IJAMSR 3 (7) www.ijamsr.com CrossRef: https://doi.org/10.31426/ijamsr.2020.3.7.3512

Education Commission, and Hunter Commission, many other policies, programmes, Acts and commissions are establish but till now Educational rights of children are not fulfilled. As the researcher studied various reports of governmental as well as non-governmental organization regarding the rights of the children it found that the children are depriving from their Educational rights due to one and another reasons. Researcher identified some of the examples where children are the victim of violence either in the home, society, school or in other institution, among these Child Marriage, Child Trafficking, Child Victims of Domestic Violence, and Violation of Rights of Education due to Child sexual abuse either in the home and school, Corporal Punishment and Educational Rights of children are considered by researcher. In most of the Indian schools teachers inflict corporal punishment on students for various reasons and most parents beat their children. Along with this children are physically ill-treated and humiliated on the name of Discipline. On the basis of the analysis of the reports and data retrieved from different sources it is easy to say that India is still lacking in providing the rights to children even after various commissions, laws, rules and regulations came into existence. This is the point of the discussion that 19,223 women and children were trafficked in 2016 in India. How can be securing the Educational rights of these children in this Independent India. It is the point of Discussion that what factors are there in India which forced to child Marriage and becomes the hurdle in Education. The reasons may be Poverty, Orthodoxy, and unawareness about benefits of Education in future and how it contributes personal social and societal development. As well the reports of UNICEF shows that the children who becomes the victims of domestic violence suffer long-term physical and psychological damage that impairs their ability to learn and socialize, and makes it difficult for them to perform well in school. It can be concluded that children needs to be secure in India. India is far back even after Seventy Years of Independence. The children are not access their basic Educational Rights, they are vulnerable in one another way. 
IJAMSR 3 (7) www.ijamsr.com CrossRef: https://doi.org/10.31426/ijamsr.2020.3.7.3512

\section{References}

1) Armstrong, M. (2006). A Handbook of Human resource Management Practice, Tenth Edition, Koran Page Publishing, London, , p. 264

2) Diuguid, Darraya.R. in( 2009). Studied Student Teachers Awareness, Preparedness and Attitudes of Issues Related to high Poverty Schools. . Journal of Experimental Education June 1955.

3) Christen, M., Ayer, G. and Sober man, D. (2006). Job Satisfaction, Job Performance, and Effort: A Reexamination Using Agency Theory, Journal of Marketing, January, Vol. 70, pp. 137-15

4) Davis, K. and Nostrum, J.W. (1985). Human Behavior at work: Organizational Behavior, 7 editions, McGraw Hill, New York, p.109

5) Herzberg, H. F. (1976). MotivationHygiene Profiles, p. 20 George, J.M. and Jones, G.R. (2008). Understanding and Managing Organizational behavior, Fifth Edition, Pearson/Prentice Hall, New Yersey, $p .78$

6) Hop pock, R. (1935). Job Satisfaction, Harper and Brothers, New York, p. 47

7) Kaminski, B.S. (2007). Encyclopedia of Business and Finance, Second edition, Thompson Gale, Detroit, p. 446

8) Lawler, E.E. III and Porter, L.W. (1967). The Effect of Performance on Job Satisfaction, Industrial Relations, pp. 20-28

9) Locke, E.A. and Latham, G.P. (1990). A theory of goal setting and task performance, Prentice Hall, p.4 Lufthansa, F. (1998). Organizational Behavior, 8 Editions, McGraw-Hill/Irwin, Boston, $p$. 147

10) Mullins, J.L. (2005). Management and organizational behavior, Seventh Edition, Pearson Education Limited, Essex, p. 700
11) Mrunalini, T. \& Sankaraih.B. (2010). Study on Attitudes and Reflections of Prospective Teachers on Environmental Concerns. Social psychology of Education, 6,61-90.

12) Pandey, $R$ and Tripathy,(2006). Attitude towards teaching, Harper and Brothers, New York, p. 47

13) Rue, L.W. and Byers, L. (2003). Management, Skills and Application, 10 ed., McGraw-Hill/Irwin, New York, p. 259

14) Reno and Nanda (1999) ). A theory of goal setting and task performance, Prentice Hall, p.4

15) Specter, P.E. (1997). Job satisfaction: Application, assessment, causes and consequences, Thousand Oaks, Corsage Publications, Inc Stat, D. (2004). The Rutledge Dictionary of Business Management, Third edition, Rutledge Publishing, Detroit, p. 78

16) Sweeney, P.D. (2005). Organizational Behavior, Solutions for Management, McGraw-Hill/Irwin, New York. 57

17) Sunitha and Badola, (2010). Study on studied, IGNOU (B.ED.)Teacher Trainees Attitude towards Awareness of the Fundamental Rights of Secondary school Students rights of secondary school students. . Journal of Higher Education Policy Management, vol.21, no.2, pp. 203 214.

18) Selvaraj Gnanaguru, A \& Suresh Kumar, $M$, in (2008). Study on under Achievement of B.Ed Students in Relation to their Home Environment and Attitude towards Teaching. . Journal of Higher Education Policy Management, vol.21, no.2,pp. 203214.

19) UNESCO, (1998). World Declaration on Education for All. Adapted by the World conference on Education for All meeting Basic Learning Needs. Jomtin, Published by UNESCO. 